\title{
МЕТОДИЧНІ АСПЕКТИ ВИКЛАДАННЯ І РОЛЬ НАВЧАЛЬНОЇ ДИСЦИПЛІНИ «ФАРМАЦЕВТИЧНЕ ТА МЕДИЧНЕ ТОВАРОЗНАВСТВО» В СИСТЕМІ ПІДГОТОВКИ МАЙБУТНІХ ФАХІВЦІВ ФАРМАЦІї
}

\author{
L. M. Svirchevska, O. G. Moroz, Zh. V. Osinska \\ Zhytomyr Basic Pharmaceutical Vocational College Zhytomyr Regional Council \\ METHODICAL ASPECTS OF TEACHING AND ROLE OF THE \\ EDUCATIONAL DISCIPLINE “PHARMACEUTICAL AND MEDICAL \\ COMMODITY SCIENCE” IN THE SYSTEM OF PREPARATION OF THE \\ FUTURE PHARMACY PROFESSIONALS
}

\begin{abstract}
Анотація. У статті представлений досвід викладання вибіркової дисципліни «Фармацевтичне та медичне товарознавство» для студентів спеціальності 226 «Фармація, промислова фармація» першого (бакалаврського) рівня в Житомирському базовому фармацевтичному фаховому коледжі денної форми навчання.

Вивчення дисципліни спрямоване на підготовку майбутніх фахівців фармації до виконання професійних товарознавчих функцій, пов'язаних із забезпеченням аптечних та лікувально-профілактичних закладів, населення лікарськими препаратами, медичними виробами та парафармацевтичними засобами, використовуючи законодавчу та нормативну базу України й дотримуючись вимог належних практик у процесі професійної діяльності.

У статті висвітлені та обгрунтовані питання актуальності вивчення студентами дисципліни, ії значення для формування професійної компетентності майбутніх спеціалістів та показана міждисциплінарна інтеграція.

Сучасний фармацевтичний ринок вимагає від фармацевта глибоких знань, товарознавчого мислення і практичної майстерності, що, у свою чергу, потребує застосування в навчальному процесі більш прогресивних методів навчання. Використання інтерактивних методів оптимізує навчальний процес і потребує особливої уваги.

У статті розглянуті питання особливості організації дистанційного навчання, що здійснюються в умовах пандемії COVID-19, переваги застосування сучасних мобільних технологій з метою стимулювати студентів до самоосвіти, спонукати до самостійного оволодіння знаннями, сприяти професійному визначенню.

Окреслюються питання організації самостійної роботи та ії значення в засвоєнні студентами курсу дисципліни.

Окрема увага приділяється ролі особистості викладача, який має створювати сприятливі умови для розкриття творчого потенціалу студента та сприяти майбутній професійній самореалізації.
\end{abstract}

Ключові слова: вибіркова дисципліна; фармацевт; асортимент товарів; товарознавчі функції.

Abstract. The article presents the experience of teaching the elective course "Pharmaceutical and medical commodity science" for students from the subject area 226 Pharmacy, Industrial Pharmacy of the first (bachelor`s) level in Zhytomyr college of pharmacy, full-time studying.

The study of the discipline is aimed to train future pharmacy professionals to perform professional commodity functions related to the provision of pharmacies and medical institutions, the population with medicines, medical devices and parapharmaceuticals, using the legal and regulatory framework of Ukraine and adhering to the requirements of the appropriate practices in the professional activities.

The article represents and highlights the relevance of students' study of the discipline, its importance for the formation of professional competence of future professionals and shows the interdisciplinary integration.

The modern pharmaceutical market requires from the pharmacist deep knowledge, commodity thinking, commodity skills, which in its turn requires using of more advanced teaching methods in the educational process. The use of interactive methods optimizes the learning process and requires special attention.

() Л. М. Свірчевська, О. Г. Мороз, Ж. В. Осінська 
In the article are considered the questions of features of the organization of distance learning, that is made in conditions of COVID-19 pandemic, the adventages of using the modern mobile technologies with a goal to stimulate students to self-education, to induce them to self-acquisition of knowledge, to promote professional determination.

The questions of organization of the independent work and its value in mastering by students of a course of discipline are outlined.

Special attention is focused on the role of teacher's personality, who ought to create the favorable conditions for the disclosure of the creative potential of the student, to develop his cognitive interests and individual abilities, to form a positive motivation to learn and to promote future professional self-realization.

Key words: selective discipline; pharmacist; commodities assortment; commodity functions.

Вступ. Глобалізація світової торгівлі, насичення сучасного фармацевтичного ринку різноманітним асортиментом товарів, орієнтація на динамічні потреби споживачів, конкуренція товаровиробників, пресинг неякісної, фальсифікованої і не ліцензованої продукції зумовили необхідність свідомого управління асортиментом та якістю товарів. До вирішення цих завдань причетна товарознавча наука і освіта [4]. Ринок напружено намагається отримати фахівця-товарознавця, а сучасна освіта - адаптуватися до вимог суспільства. Завданням вищої школи на цьому етапі повинна стати підготовка висококваліфікованого спеціаліста, креативного, вмотивованого на успіх, з усвідомленням соціального значення обраної професії.

Особливість сучасної педагогічної технології полягає у свободі вибору курсів, дисциплін, факультативів студентом. Адже європейська модель навчання дозволяє вибрати навчальні дисципліни, які відповідають особистим інтересам студента, дозволяють виокремити його здібності, побачити й окреслити, до якого типу професійної роботи має прихильності студент і до якої кар’єри він себе може готувати [4].

Навчальна дисципліна «Фармацевтичне та медичне товарознавство» $€$ вибірковою дисципліною й обираючи її студенти розуміють, що інвестують свої зусилля і енергію «в культуру товарознавчої майстерності, у спосіб мислення категоріями глобального масштабу - «здоров’я нації», «збереження нації», «генофонд», i що найголовніше, створюють стратегію погляду молоді на якість життя» [4].

Мета статті - теоретично обгрунтувати і проаналізувати особливості викладання та методичного забезпечення вибіркової навчальної дисципліни «Фармацевтичне та медичне товарознавство», показати її роль у навчальному процесі і в майбутній професійній діяльності фармацевта та зробити висновки щодо оптимізації навчального процесу.

Теоретична частина. Будь-яка наука, що репрезентує ту чи іншу галузь знань, спирається на три опори: об’єкт, предмет і методи пізнання. На відміну від інших галузей знань, термін «товарознав- ство» містить у собі складові елементи як об’єкта науки (товар), так і предмет його дослідження (знати) [7]. Тобто товарознавство - це сукупність знань про товар, комплексна наукова дисципліна, яка системно вивчає товари на всіх етапах життєвого циклу, методи пізнання їхньої споживчої вартості, закономірності формування асортименту і вимог до якості для забезпечення ефективності їх виробництва, обігу та споживання [5].

Товарознавство - наука фундаментальна і разом 3 тим - наука тонка, це особливий світ товарів, i особливий спосіб його бачення, це здатність відчувати і прогнозувати якість товарів, від чого буде залежати наше здоров'я, а отже, і якість нашого життя [4]. Особливо, коли йдеться про фармацевтичні і медичні товари.

Фармацевтичне та медичне товарознавство - це наукова дисципліна, яка вивчає споживчі властивості фармацевтичних і медичних товарів на всіх етапах їх життєвого циклу.

В умовах ринкових відносин і загострення конкурентної боротьби за споживача велике значення в системі підготовки фармацевтів має медичне та фармацевтичне товарознавство [5].

Щороку через аптечну мережу реалізуються у різноманітному асортименті лікарські засоби [5], медичні вироби, парафармацевтична продукція. Для того щоб орієнтуватися в арсеналі цих товарів, здійснювати їх приймання, проводити товарознавчий аналіз, організовувати відповідні умови зберігання, транспортування та реалізації продукції, провізор має володіти знаннями в галузі товарознавства [5].

Метою вивчення дисципліни є формування фахової компетентності для виконання товарознавчих функцій, пов'язаних із забезпеченням аптечних і лікувальних закладів фармацевтичними та медичними товарами, управління якістю товарів із дотриманням вимог належних фармацевтичних практик, чинних законодавчих та нормативних документів.

Вивчається дисципліна в VI семестрі, коли студенти вже мають достатньо міцне професійне підгрунтя й озброєні знаннями з хімічних, біологічних, 
філологічних, фізичних, фармацевтичних дисциплін. Фактично, ми маємо справу з майже сформованими спеціалістами, які мають міцний запас теоретичних знань, практичний досвід після проходження курсу виробничих практик в аптеці, дехто зі студентів працював чи працює в аптеці в нічну зміну, а тому надзвичайно умотивовані до вивчення дисципліни, і завдання викладача - систематизувати, відновити, доповнити вже раніше отримані студентами знання i, звичайно, озброїти новими, сучасними, актуальними, урізноманітнити методику викладання, сприяти саморозвитку студента.

Вивчення дисципліни розраховано на 90 год, 3 них лекційних - 16, практичних - 32 і самостійної роботи - 42 год. Видами навчальної діяльності, згідно з навчальним планом, є лекційні, практичні заняття, самостійна робота студентів. Теми лекційних занять висвітлюють загальні та спеціальні питання з курсу дисципліни. Матеріал викладається на рівні сучасних наукових та практичних даних із метою формування у студентів необхідного обсягу теоретичних знань. Лекційний курс представлений у вигляді восьми лекцій, до кожної лекції розроблені мультимедійні презентації, практикується демонстрація фрагментів фільмів, відеороликів, що допомагає кращому сприйняттю і засвоєнню викладеного матеріалу.

Формування професійної компетентності майбутнього фармацевта можливе лише в поєднанні набутих теоретичних знань і практичних умінь та навичок, які формуються, насамперед, під час практичного навчання. Практичні заняття передбачають: проведення етапів товарознавчого аналізу фармацевтичних та медичних товарів з урахуванням вимог діючих законодавчих актів, нормативних документів і стандартів; вирішення проблемноситуаційних задач; розв'язання тестових завдань. Мета практичних занять - поглиблення, деталізація, закріплення знань, отриманих студентами під час лекційних занять та самостійної роботи. Набуття студентами товарознавчих функцій і навичок по визначенню якості товарів потребує більш глибоких лабораторних знань і дослідницьких навичок із проведення ідентифікації, стандартизації, виявлення можливої фальсифікації товарів. Особливістю методологічного підходу до практичних занять $€$ те, що товарознавча підготовка майбутнього фахівця вимагає по своїй суті дослідництва. Принципіальна освітницька парадигма «освіта як культура» доповнюється іншою - освіта як навичка, як здібність. Але вона ж і визначає зміст роботи фармацевта як товарознавця - знати товар, саме знати і зробити його кращим, кориснішим, безпечнішим [4].

На кожному практичному занятті передбачено вивчення асортименту сучасних медичних та фармацевтичних товарів, парафармацевтичної продукції, їх класифікації, способу застосування, стандартизації тощо. Студенти проводять товарознавчий аналіз товарів, що включає органолептичний і візуальний контроль, пакування, маркування товару, визначення країни-виробника за штриховим кодом, перевірку контрольної цифри коду, перевірку комплектності товару, технічних вимог тощо. В ході дослідження студенти набувають практичних навичок, які потім активно будуть застосовувати в майбутній роботі.

Набуття товарознавчих навичок студентами можливе лише при достатньому методичному забезпеченні занять і використанні наочності, якою $€$ натуральні зразки товарів і яка сприяє не лише придбанню умінь і навичок проводити аналіз якості товарів, а і сприяє детальнішому знайомству 3 асортиментом, споживчими властивостями товарів, які вивчаються [6]. Кожне практичне заняття забезпечено достатньою мірою навчальною наочністю, з якою активно працюють студенти, вивчають товари, здійснюють товарознавчий аналіз, роблять висновки стосовно якості товару і результати записують у робочий зошит.

Робочий зошит, який розробили викладачі коледжу, допомагає студенту більш ефективно опрацьовувати навчальний матеріал, зекономити аудиторний час та підвищити якість підготовки до практичних занять. У зошиті до кожної теми зазначено перелік питань, які розглядатимуться на занятті, а також вказані практичні, ситуаційні завдання, план самопідготовки, тести для самоконтролю.

Забезпечення здобувачів вищої освіти навчально-методичними посібниками, робочим зошитом, технічними засобами навчання, наочністю дають можливість викладачу вносити елементи управління в самостійну пізнавальну діяльність студента і тим самим сприяють набуттю глибоких знань, практичних навичок, самоосвіті як провідному фактору майбутньої самореалізації.

3 метою розвитку пізнавальної активності та оптимізації засвоєння знань залучаємо студентів до участі в лекціях, практичних заняттях з мінідоповідями чи міні-відеопрезентаціями. Поширеною практикою стало створення студентами індивідуальних проектів із використанням інтернет-ресурсів. При підготовці до практичних занять 
студенти в рамках тематики заняття самостійно обирають тему з подальшим захистом («Історичні аспекти розвитку товарознавства як наукової дисципліни», «Стандартизація та сертифікація як засіб забезпечення безпеки та якості товарів», «Споживча тара для фармацевтичної промисловості», «Історія виникнення окулярів», «Сучасні пакувальні матеріали», «Мінеральні води України, застосування в медицині» та ін.), що надає практичної спрямованості та підвищує ефективність засвоєння курсу.

Нині в студентській аудиторії відбувається певна переорієнтація від пізнавального характеру навчальної діяльності до самостійної творчої роботи, яка сприяє розвитку наукової ерудиції, світогляду, вмінню вести аргументовану полеміку тощо [7]. Для підготовки питань, винесених на самостійне опрацювання, студенти працюють 3 навчальною літературою, підручниками, робочим зошитом.

Оцінювання знань студентів проводиться на всіх етапах протягом усього курсу навчання. На кожному практичному занятті здійснюється поточне оцінювання, що дозволяє отримати негайну інформацію про досягнення студентів у навчанні під час певного модуля. Викладач отримує дані про доцільність застосування тих чи інших методів та прийомів навчання і своєчасно корегувати недоліки [4]. Надаємо перевагу тестуванню як методу, що дозволяє охопити велику групу студентів, зекономити аудиторний час, зорієнтуватися на сучасні технічні засоби навчання і використання комп’ютерних навчальних та контролюючих систем; збільшення об’єктивності педагогічного контролю, мінімізації суб’єктивного фактора під час оцінювання відповідей [1].

Сучасна товарознавча наука складна і різноманітна, у змінних ринкових умовах вона постійно розвивається, набуває нових теоретичних знань, умінь і практичних навичок [4]. 3 метою оптимізації навчального процесу на заняттях активно застосовуються інтерактивні методи. Під час такого навчання у режимі бесіди, діалогу, при моделюванні життєвих ситуацій, коли викладач і студент виступають як рівноправні суб’єкти навчального процесу, студенти навчаються критично мислити, розв'язувати складні проблеми на основі аналізу обставин і відповідної інформації, робити висновки, приймати продумані рішення, використовувати професійну товарознавчу термінологію, брати участь у дискусії, спілкуватися з іншими людьми [3].

В умовах пандемії COVID-19 перед викладачем постав ряд завдань, пов'язаних із тим, як, опира- ючись на використання сучасних інформаційних технологій, організувати навчальний процес, допомогти студентам глибше зрозуміти і засвоїти навчальний матеріал, стимулювати їх до самоосвіти, розвивати мотивацію, самоорганізацію, сприяти професійному визначенню. Дистанційне навчання за допомогою сучасних мобільних засобів, зокрема з використанням платформи LMS Moodle, що $є$ поширеним веб-ресурсом у коледжі, Google Classroom, Zoom, Google Meet, стало незамінним і зайняло чільне місце в освітньому процесі, оскільки при грамотній його організації може забезпечити якісну освіту, що відповідає актуальним вимогам сьогодення.

Та все ж головним чинником, що визначає якість освітнього процесу, є особистість викладача. На думку багатьох дослідників, найбільш продуктивними є поєднання діяльності наукового працівника та педагога, а всі інші види діяльності нею інтегруються та проявляються в ній. Від ефективності роботи викладача, його сили впливу на свідомість та емоції студентів, індивідуальних характеристик багато в чому буде залежати формування особистісних та професійних якостей майбутнього фахівця, здатного працювати в сучасних ринкових умовах.

Висновки та перспективи подальших досліджень. Товарознавча підготовка майбутнього фармацевта є необхідним і вагомим елементом у формуванні його як спеціаліста. Знання і навички, отримані при вивченні дисципліни, необхідні в майбутній професійній діяльності, направленій на забезпечення населення необхідним асортиментом якісних лікарських засобів, медичних виробів, парафармацевтичною продукцією. Вивчення дисципліни $є$ актуальним, своєчасним, затребуваним, особливо в умовах сучасного фармацевтичного ринку.

Для підвищення рівня підготовки спеціалістів необхідна постійна робота викладача над своєю педагогічною і професійною майстерністю, пошук нових форм і напрямків навчання, використання інноваційних методів, постійне оновлення методичних матеріалів, поповнення матеріальної бази дисципліни новими сучасними видами наочності.

Перспективний напрямок подальшої роботи ми вбачаємо в удосконаленні методики викладання, в подальшому впровадженні інноваційних технологій, особливо в умовах дистанційного навчання, а також у вивченні та аналізі особливостей викладання даної дисципліни у провідних вітчизняних та закордонних вищих навчальних закладах фармацевтичного профілю. 


\section{Список літератури}

1. Дубініна О. Оцінювання знань студентів з англійської мови для професійного спілкування / О. Дубініна // Товарознавство і торговельне підприємство: фахова професіоналізація, дослідження, іновації : матеріали Міжнар. наук.-практ. конф. (Київ, 15-16 квітня 2009 р.) / відп. ред. А. А. Мазаракі. - К. : Київ. нац. торг.-екон. ун-т, 2009. - С. 447-449.

2. Косачова Л. Формування комунікативних здібностей майбутніх фахівців / Л. Косачова // Освіта. Технікуми. Коледжі. - 2017. - № 3 (43). - С. 56-59.

3. Кулаженко О. Застосування інтерактивних технологій викладання іноземних мов за професійним спрямуванням на товарознавчому факультеті / О. Кулаженко, Т. Кліменко // Товарознавство і торговельне підприємство: фахова професіоналізація, дослідження, іновації : матеріали Міжнар. наук.-практ. конф. (Київ, 15-16 квітня 2009 р.) / відп. ред. А. А. Мазаракі. - К. : Київ. нац. торг.екон. ун-т, 2009. - С. 455-457.

4. Малигіна В. «Текстоцентризм» у моделі підготовки фахівця з товарознавства» / В. Малигіна // Товарознавство і торговельне підприємство: фахова професіоналізація,

\section{References}

1. Dubinina, O. (2009). Otsinyuvannya znan studentiv z anhliyskoyi movy dlya profesiynoho spilkuvannya [Evaluation of students\&apos; knowledge of English for professional communication]. Tovaroznavstvo i torhovelne pidpryemstvo: fakhova profesionalizatsiya, doslidzhennya, inovatsiyi: materialy Mizhnarodnoyi naukovopraktuchnoyi konferentsiyi - Commodity science and trade enterprise: professional professionalization, research, innovations: materials of international scientific-practical conference. A. A. Mazaraki (Ed.). Kyiv: Kyiv. Natsionalnyi torhovoekonomichnyi universytet [in Ukrainian].

2. Kosachova, L. (2017). Formuvannya komunikatyvnykh zdibnostey maybutnikh fakhivtsiv [Formation of communicative abilities of future specialists]. Osvita. Tekhnikumy. Koledzhi - Education. Technical. Colleges, 3, 56-59 [in Ukrainian].

3. Kulazhenko, O. \& Klimenko, T. (2009). Zastosuvannya interaktyvnykh tekhnolohiy vykladannya inozemnykh mov za profesiynym spryamuvannyam na tovaroznavchomu fakulteti [Application of interactive technologies of teaching foreign languages by professional orientation at the faculty of commodity]. Tovaroznavstvo i torhovelne pidpryyemstvo: fakhova profesionalizatsiya, doslidzhennya, inovatsiyi: materialy Mizhnarodnoyi naukovopraktuchnoyi konferentsiyi - Commodity science and trade enterprise: professional professionalization, research, innovations: materials of international scientific-practical conference. A. A. Mazaraki (Ed.). Kyiv: Kyiv. Natsionalnyi torhovoekonomichnyi universytet [in Ukrainian].

4. Malygina, V. (2009). «Tekstotsentryzm» u modeli pidhotovky fakhivtsya z tovaroznavstva» ["Textocentrismus” дослідження, іновації : матеріали Міжнар. наук.практ. конф. (Київ, 15-16 квітня 2009 р.) / відп. ред. А. А. Мазаракі. - К. : Київ. нац. торг.-екон. ун-т, 2009. C. 52-54.

5. Медичне та фармацевтичне товарознавство : практикум / В. Г. Дем'яненко, В. А. Афанасьєва, А. В. Проскочило, С. В. Бреусова ; за ред. проф. В. Г. Дем'яненка. К. : ВСВ «Медицина», 2010. - 296 с.

6. Методика викладання товарознавчих дисциплін у вищій школі : навч. посіб. для студ. вищ. навч. закл. / за ред. Н. Б. Аннєнкової, В. І. Бідаша ; Держ. закл. «Луган. нац. ун-т імені Тараса Шевченка». - Луганськ : Вид-во ДЗ «ЛНУ імені Тараса Шевченка», 2012. - 160 с.

7. Пугачевський Г. Ф. Методологія товарознавства: структурні трансформації на засадах конвергенції / Г. Ф. Пугачевський // Товарознавство і торговельне підприємство: фахова професіоналізація, дослідження, іновації : матеріали Міжнар. наук.-практ. конф. (Київ, 15-16 квітня 2009 р.) / відп. ред. А. А. Мазаракі. - К. : Київ. нац. торг.-екон. ун-т, 2009. - С. 60-63.

in the model of training a specialist in commodity]. Tovaroznavstvo i torhovelne pidpryyemstvo: fakhova profesionalizatsiya, doslidzhennya, inovatsiyi: materialy Mizhnarodnoyi naukovopraktuchnoyi konferentsiyi - Commodity science and trade enterprise: professional professionalization, research, innovations: materials of international scientific-practical conference. A. A. Mazaraki (Ed.). Kyiv: Kyiv Natsionalnyi torhovo-ekonomichnyi universytet [in Ukrainian].

5. Demyanenko, V.H., Afanasyeva, V.A., Proskochylo, A.V., \& Breusova, S.V. (2010). Medychne ta farmatsevtychne tovaroznavstvo: praktykum [Medical and pharmaceutical commodity science: workshop]. Kyiv: Medytsyna [in Ukrainian].

6. Annyenkova, N.B., \& Bidash, V.I. (Ed.). (2012). Metodyka vykladannya tovaroznavchykh dystsyplin u vyshchiy shkoli. Navchalnyi posibnyk dlia studentiv vyshchykh navchalnykh zakladiv [Methods of teaching commodity disciplines in tertiary education: educational manual for students of higher education] [in Ukrainian].

7. Pugachevskyi, G.F. (2009). Metodolohiya tovaroznavstva: strukturni transformatsiyi na zasadakh konverhentsiyi [Methodology of commodity science: structural transformations on the basis of convergence]. Tovaroznavstvo i torhovelne pidpryyemstvo: fakhova profesionalizatsiya, doslidzhennya, inovatsiyi: materialy Mizhnarodnoyi naukovopraktuchnoyi konferentsiyi - Commodity science and trade enterprise: professional professionalization, research, innovations: materials of international scientificpractical conference. A.A. Mazaraki (Ed.). Kyiv: Kyiv. Natsionalnyi torhovo-ekonomichnyi universytet [in Ukrainian].

Отримано 02.09.21 Рекомендовано 09.09.21 